\title{
The Effect of Perception of Black Consumer Behavior on the Job Enthusiasm and Self-esteem of Beauty Service Workers
}

\author{
Myo-sun Choi ${ }^{1}$, Ki-bbeum Jung ${ }^{1}$, Young-jo Lee ${ }^{2 *}$ \\ ${ }^{1}$ Department of Health Science, Dongduk Women's University, Seoul, Korea \\ ${ }^{2}$ Department of Hair Beauty Course, Kyung- In Women's University, Incheon, Korea
}

\author{
*Corresponding author: Young-jo Lee, \\ Department of Hair Beauty Course, Kyung- \\ In Women's University, 63, Gyeyangsan-ro, \\ Gyeyang-gu, Incheon 21041, Korea \\ Tel.: +82 329400114 \\ Email: leewha88@naver.com
}

Received April 16, 2020

Revised April 28, 2020

Accepted May 15, 2020

Published June 30, 2020

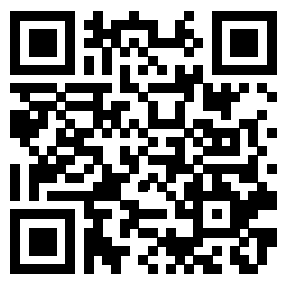

\begin{abstract}
Purpose: The purpose of this study was to determine the effects of black consumers' perception of behavior on job enthusiasm and self-respect among beauty industry workers. Methods: The survey was conducted for 1 month beginning March 2, 2020, for beauty service workers in Seoul, Incheon, and Gyeonggi Province, and a total of 293 responses were analyzed. SPSS version 25.0 program was used to analyze frequency, factor analysis, reliability analysis, correlation analysis, one-way analysis of variance, post-verification, and multiple regression analysis. Results: The perception of behavior of black consumers was found to be more in their 40s than in their 20s and 30s. Second, black consumers' perception of behavior showed a negative correlation with job enthusiasm and self-respect, and job enthusiasm and self-respect showed a positive correlation with each other. Conclusion: The results of this study provide basic data for the development of the beauty industry, and it is hoped that systematic human resources management will be planned and promoted to address the perception of behavior of black consumers and improve the job enthusiasm of beauty industry workers.
\end{abstract}

Keywords: Beauty service, Black consumer, Behavioral perception, Job engagement, Self-respect

\section{Introduction}

"고객을 만족시켜라, 가장 처음에도 가장 나중에도 그리고 항상 (satisfy your customers, first and last, and always)"이라는 말 은 세계적인 의류 브랜드 베네통의 회장 루치아노 베네통(Luciano Benetton)의 경영 철학이다. 베네통의 경영 철학처럼 고객만족은 기 업의 성패를 절대적으로 좌우한다. 따라서 현대사회에서 고객만족이 란, 기업경영이익의 중요한 수단이므로 경영활동의 초점을 대부분 고객만족에 맞추고 있다. 그러나 이러한 점을 악용하여 고의적으로 기업에 무리한 보상을 요구하는 악성적 불평행동 소비자가 점차 늘 어나고 있다(Lee \& Kim, 2016). 대부분의 기업들은 이러한 소비자 의 악성적 요구로 인해 발생하는 부정적인 파급효과를 피하고자 부 당함을 알면서도 소비자의 악성적 요구를 수용하고 있다. 이처럼 악 성민원을 고의적으로 제기하여 기업의 피해를 유발하는 소비자 즉 블랙컨슈머'가 점차 늘어나고 있다. 정리하자면 기업의 고객만족 경 영 철학과 소비자의 과도한 권리 의식에 기초한 사회적 패러다임이
블랙컨슈머를 탄생시켰다.

블랙컨슈머(black consumer)란 악성을 뜻하는 블랙(black)과 소 비자란 뜻의 소비자(consumer)를 합친 신조어로써 기업을 상대로 구매한 상품이나 서비스에 대하여 보상금 등을 취득할 목적으로 고 의적 악성 민원을 제기하는 소비자를 말한다(Lee et al., 2013). 블 랙컨슈머는 학문적으로 규정되기 보다는 언론에서 사용되어왔고, 2012년 국립국어원에서는 누리꾼들이 제안을 검토하여 블랙컨슈머 의 의미를 잘 나타낼 수 있는 단어로 '악덕소비자'를 선정하였다. 블 랙컨슈머와 유사한 의미로 불량고객이 있다. 하지만 이 두 단어는 서 로 다른 개념으로 명확한 차이가 있다.

Lee et al. (2013)은 불량고객은 통상적 제품이나 서비스 대한 하 자에 대한 불만을 사적 또는 공적 행동으로 표출하는 반면 블랙컨슈 머는 기업, 제조업체, 서비스 제공을 직접 방문하여 문제를 계획적 으로 제기하여 과도한 보상을 요구한다는 차이점이 있다고 하였다. 대한상공회의소에서 기업을 대상으로 소비자의 행동실태를 조사한 결과 악성 클레임으로 인하여 과도한 보상을 요구한 사례가 2007년 
$61 \%$ 에서 2018 년 $87.3 \%$ 로 증가하였다. 하지만 대부분의 기업들은 기업이미지를 고려하여 이런 소비자의 과도한 요구에도 불구하고 맞 대응을 하지 못하는 상태이다. 이렇듯 고객의 불량행동은 기업에 막 대한 재정적, 사회적 손실을 가져오기 때문에 이를 방지하고 대처하 기 위한 다양한 전략들이 부각되고 있다(Fullerton et al., 2004).

뷰티 산업은 인적 서비스를 제공하는 산업으로 뷰티 종사자와 고 객의 상호작용을 통한 부용예술이다(Son \& Park, 2017). 이때 뷰티 종사자의 전문성과 숙련도와는 상관없이 고객의 주관적 입장에서 서 비스 만족도가 판단된다. 따라서 뷰티 종사자와 고객간 분쟁의 소지 가 높으며 이와 같은 이유로 다른 산업영역보다 뷰티 산업에서 다양 한 서비스 불만족 사례 발생과 블랙컨슈머의 출현 가능성이 높아질 것으로 예상된다.

또한 뷰티 산업의 종사자들은 남성보다 여성의 비율이 높은 편이 다. Jo \& Hwang (2013)은 중년여성들이 신체적 측면에서 노화를 경 험하게 되고 심리적 스트레스로 많은 부작용과 질병에 쉽게 노출되 고 있다고 하였다. 이러한 측면에서 뷰티 종사자들은 블랙컨슈머의 출현으로 발생한 정신적 육체적 스트레스에 더 취약할 수밖에 없다.

현재까지의 블랙컨슈머와 관련된 선행 연구들을 살펴보면 Shin \& Shin (2014)은 소비자의 심리특성이 블랙컨슈머의 행동 및 삶의 만 족도에 영향을 미친다고 주장하였으며, Kim et al. (2016)은 블랙컨 슈머의 불량행동이 호텔종사원의 직무소진과 고객지향성에 영향을 미친다고 하였다. Jang \& Yoon (2019)은 블랙컨슈머의 행동에 대한 항공사 객실승무원의 감정노동이 직무지속의사에 영향을 주어 이직 의사에 영향을 준다고 하였다. 그럼에도 불구하고 뷰티 산업측면에
서 블랙컨슈머에 대한 연구는 활발하지 않다.

본 연구에서 정의하는 직무열의는 어떠한 일을 달성하기 위해 혼 신의 힘을 기울이는 마음으로 주어진 업무나 그 책임을 다하기 위해 적극적이고 능동적인 태도이다. 따라서 직무열의는 업무 시에 긍정 적인 영향을 미치며, 나아가 자신의 직무열의를 다른 사람에게 전달 하여 개인성과만이 아닌 조직 성과에도 크게 영향을 미친다(Khan, 1990).

선행연구(Hong \& Koh, 2013; Jeon, 2008; Seo \& Park, 2018) 에서는 피부관리사의 직무 스트레스와 사회 심리적 스트레스가 높을 수록 이직 성향이 높아진다고 하였다. 이와 같은 이유로 고객들의 불 량행동이 높을수록 뷰티 종사자들의 직무열의에도 영향을 미칠 것으 로 예상된다.

그리고 본 연구에서 정의하는 자아존중감은 개인 스스로 자신의 가치를 긍정적 또는 부정적으로 평가하는 측면이다. Baumeister et al. (2003)은 자아 존중감이 높은 사람은 친 사회적인 경향이 있지 만 낮은 사람은 반사회적 행동을 보일 가능성이 높다고 하였다. 즉, 자아존중감은 정신건강의 핵심이며 대인관계, 사회적응성에 중요한 요소이다(Ryu \& Kim, 2020).

따라서 본 연구의 목적은 뷰티 서비스 종사자가 지각한 블랙컨슈 머의 행동지각이 직무열의 및 자아존중감에 어떠한 영향을 미치는지 규명하고자 하는 것이다. 아울러 본 연구를 통하여 사회적 문제로 여 겨지고 있는 뷰티 서비스 영역에서의 블랙컨슈머에 대한 해결방안과 뷰티 서비스 종사자들의 직무 열의 및 자아존중감 향상에 유용한 자 료가 될 수 있길 바란다.

Table 1. General characteristics of consumers

\begin{tabular}{|c|c|c|c|c|}
\hline Category & & Frequency & Percentage & Cumulative percentage \\
\hline \multirow{4}{*}{ Age } & $20_{s}$ & 43 & 14.7 & 14.7 \\
\hline & $30_{s}$ & 107 & 36.5 & 51.2 \\
\hline & $40_{s}$ & 65 & 22.2 & 73.4 \\
\hline & $50_{\mathrm{S}}$ or older & 78 & 26.6 & 100.0 \\
\hline \multirow{4}{*}{ Major } & Hair beauty & 146 & 49.8 & 49.8 \\
\hline & Skin beauty & 94 & 32.1 & 81.9 \\
\hline & Make up & 24 & 8.2 & 90.1 \\
\hline & Nail art & 29 & 9.9 & 100.0 \\
\hline \multirow{5}{*}{ Position } & Assistant & 20 & 6.8 & 6.8 \\
\hline & Hair stylist & 54 & 18.4 & 25.3 \\
\hline & Supervisor & 58 & 19.8 & 45.1 \\
\hline & Manager & 143 & 48.8 & 93.9 \\
\hline & Others & 18 & 6.1 & 100.0 \\
\hline \multirow{5}{*}{ Service life } & Not more than 5 years & 72 & 24.6 & 24.6 \\
\hline & $6-10$ years & 50 & 17.1 & 41.6 \\
\hline & $11-15$ years & 45 & 15.4 & 57.0 \\
\hline & $16-20$ years & 41 & 14.0 & 71.0 \\
\hline & More than 21 years & 85 & 29.0 & 100.0 \\
\hline Total & & 293 & & 100.0 \\
\hline
\end{tabular}




\section{Methods}

\section{1. 연구의 문제}

본 연구의 문제는 다음과 같이 설정되었다.

첫째, 연구대상자의 인구학적 특성을 알아본다.

둘째, 블랙컨슈머의 행동지각이 직무열의에 미치는 영향을 알아본다.

셋째, 블랙컨슈머의 행동지각이 자아존중감에 미치는 영향을 알아본다. 넷째, 데이터를, 비교 분석하여 블랙컨슈머에 대한 해결방안과 뷰티 서비스 종사자들의 직무열의 및 자아존중감 향상에 유용한 자료를 제공 한다.

\section{2. 연구대상자 및 자료수집}

본 연구의 조사대상자는 헤어미용, 피부미용, 네일미용, 메이크업 등 현재 뷰티 서비스 직무에 종사하고 있는 자로 서울, 경기, 인천 지역 소 재의 근무지에서 근무중인자 300 명을 선정하였다.

자료수집은 2020년 03월 02일부터 04월 3일까지 한 달 동안 진행하 였으며 총 질문지 300 부를 배부하여 298 부를 회수하였으며, 회수된 질 문지 중 응답내용이 불성실한 5 부를 제외한 293 부를 최종 분석자료로 활용하였다.

\section{3. 측정도구}

질문지는 4 개의 범주로 나누어 인구 통계학적 특성 4 문항, 블랙컨슈 머 11 문항, 직무열의 10 문항, 자아존중감 3 문항으로 총 28 개의 측정문 항으로 선행연구를 바탕으로 구성 되어있다.

\section{4. 자료처리 및 분석방법}

수집된 자료는 Window용 사회과학 통계패키지(SPSS) 25.0을 이 용하여 처리하였다. 분석방법으로 연구대상자의 인구학적 특성을 살 펴보기 위해 빈도분석을 실시하였고, 측정도구의 타당도와 신뢰도 검증을 위해 요인분석과 신뢰도분석(Cronbach's $\alpha$ )을 실시하였다. 연령에 따른 블랙컨슈머 행동지각의 평균 차이 분석을 위해 일원분 산분석(one-way ANOVA)과 사후검증(Scheffe's)을 실시하였고, 블 랙컨슈머와 직무열의, 자아존중감 간의 상관관계를 분석하였으며, 블랙컨슈머 행동지각이 직무열의와 자아존중감에 미치는 영향을 살 펴보기 위해 다중회귀분석(multi-regression)을 실시하였다.

\section{Results}

\section{1. 연구대상자의 인구학적 특성}

본 연구는 뷰티 서비스 종사자의 블랙컨슈머 행동지각이 직무열 의 및 자아존중감에 미치는 영향을 살펴본 것으로 표본은 뷰티 서 비스업에 종사하고 있는 293 명이다. 이들의 일반적인 특성에 대한 내용을 종합해서 살펴보면 다음의 Table 1 과 같다. 연령은 20 대 43 명(14.7\%), 30대 107명(36.5\%), 40대 65명(22.2\%), 50대 이상 78 명 $(26.6 \%)$ 으로 조사되어 30 대가 가장 많은 것으로 나타났다. 전공 은 헤어미용 146 명(49.8\%), 피부미용 94명(32.1\%), 메이크업 24 명 $(8.2 \%)$, 네일아트 29 명 $(9.9 \%)$ 로 조사되어 헤어미용 전공자가 가 장 많은 것으로 나타났고, 직급은 보조급 20 명(6.8\%), 일반급 54 명 $(18.4 \%)$, 관리자급 58 명 $(19.8 \%)$, 경영자급 143 명 $(48.8 \%)$, 기타

Table 2. Black consumer feasibility

\begin{tabular}{|c|c|c|c|c|c|}
\hline \multirow{2}{*}{ Factors } & & \multicolumn{3}{|c|}{ Components } & \multirow{2}{*}{ Cronbach's $\alpha$} \\
\hline & & 1 & 2 & 3 & \\
\hline \multirow{5}{*}{ Habitual } & Question 2 & 0.857 & & & 0.812 \\
\hline & Question 3 & 0.830 & & & 0.759 \\
\hline & Question 4 & 0.813 & & & 0.791 \\
\hline & Question 5 & 0.719 & & & 0.668 \\
\hline & Question 1 & 0.704 & & & 0.596 \\
\hline \multirow{3}{*}{ Deterrence } & Question 6 & & 0.850 & & 0.777 \\
\hline & Question 7 & & 0.821 & & 0.775 \\
\hline & Question 8 & & 0.564 & & 0.640 \\
\hline \multirow{3}{*}{ Immoderate } & Question 15 & & & 0.900 & 0.859 \\
\hline & Question 14 & & & 0.801 & 0.764 \\
\hline & Question 16 & & & 0.611 & 0.709 \\
\hline Eigenvalue & & 5.912 & 1.182 & 1.056 & \\
\hline Variance (\%) & & 53.749 & 10.744 & 9.600 & \\
\hline Cumulative (\%) & & 53.749 & 64.492 & 74.093 & \\
\hline Cronbach's $\alpha$ & & 0.902 & 0.797 & 0.816 & \\
\hline Total Cronbach's $\alpha$ & & & 0.913 & & \\
\hline
\end{tabular}

$\mathrm{KMO}=0.882, \mathrm{x}^{2}=1962.299, p<0.001$. 
18 명(6.1\%)으로 경영자급이 가장 많은 것으로 나타났다. 근무 년 수는 5년 이하 72명(24.6\%), 6-10년 50명(50\%), 11-15년 45명 (15.4\%), 16-20년 41명(14\%), 21년 이상 85명(29\%)로 21년 이상 이 가장 높게 나타났다.

\section{2. 측정도구의 타당도 및 신뢰도}

블랙컨슈머 측정도구의 타당성 검증을 위해 요인 분석한 결과 로 요인 추출방법은 주성분 분석(principle component analysis)이 며, 요인적재치의 단순화를 위해 회전방법은 직각회전인 베리맥스 (varimax) 방식을 사용하였다. 요인적재량(factor loading)은 0.05 이상인 경우 유효하게 적용하였으며 각 변수들 간의 상관관계를 살 펴보기 위해 Bartlett의 구성형 검증을 하였다. 또한 변수들 간의 적 합성 확인을 위해 Kaiser-Meyer-Olkin (KMO) 지수를 산출하였 다(Choi, 2020), 블랙컨슈머 측정도구의 타당성을 검증하고자 요 인분석을 실시한 결과 Table 2 와 같다. 블랙컨슈머 16 문항은 3 개 의 요인으로 추출되었으며, 전체 16 문항 중 $9,10,11,12,13$ 번 문
항은 요인적재치 0.05 를 충족하지 못하여 제거한 후 최종 11 문항 이 적용되었다. $\mathrm{KMO}$ 지수는 0.882 로 표본의 적합성이 확인되었으 며, Bartlett 구성형 검증치는 $\chi^{2}=1962.299, p<0.001$ 으로 변수 간 의 상관이 선형적 관계임이 확인되었고 전체변량(total variance)은 $74.093 \%$ 의 설명력을 보였다. 요인분석에 적합함이 확인된 3 개의 요인은 상습성, 억지성, 과도성으로 하위요인의 신뢰도(Cronbach's $\alpha$ ) 값은 상습성 0.902 , 억지성 0.797 , 과도성 0.816 으로 나타났으 며 전체 신뢰도 값은 0.913 으로 나타나 통계적 수용 가능한 내적일 치도를 보였다.

직무열의 측정도구의 타당성 검증을 위해 요인분석한 결과는 Table 3 과 같다. 측정도구에 사용된 10 문항 모두 요인적재치를 충 족하여 제거 없이 최종 10 문항 모두를 적용되었다. 10 문항은 1 개 의 요인으로 추출되었으며 $\mathrm{KMO}$ 지수는 0.945 로 표본의 적합성이 확인되었으며, Bartlett 구성형 검증치는 $\chi^{2}=2613.880, p<0.001$ 으로 변수 간의 상관이 선형적 관계임이 확인되었고 전체 변량 (total variance)은 69.391\%의 설명력을 보였다. 하위요인의 신뢰도

Table 3. Feasibility of job engagement

\begin{tabular}{lccc}
\hline \multirow{2}{*}{ Factors } & & Component & Cronbach's $\alpha$ \\
\cline { 3 - 4 } & & 1 & 0.811 \\
& Question 7 & 0.900 & 0.806 \\
& Question 5 & 0.898 & 0.802 \\
& Question 6 & 0.896 & 0.773 \\
& Question 9 & 0.879 & 0.762 \\
Job engagement & Question 8 & 0.873 & 0.702 \\
& Question 4 & 0.838 & 0.662 \\
& Question 2 & 0.813 & 0.566 \\
& Question 3 & 0.752 & 0.557 \\
Eigenvalue & Question 1 & 0.746 & 0.499 \\
Variance $(\%)$ & Question 10 & 0.706 & \\
Cumulative $(\%)$ & & 6.939 & \\
Cronbach's $\alpha$ & & 69.391 & \\
Total Cronbach's $\alpha$ & & 69.391 & 0.950 \\
\hline
\end{tabular}

$\mathrm{KMO}=0.945 ; \chi^{2}=2613.880 ; p<0.001$.

Table 4. Feasibility of self-esteem

\begin{tabular}{lccc}
\hline \multirow{2}{*}{ Factors } & & Component & Cronbach's $\alpha$ \\
\cline { 3 - 4 } Self-esteem & Question 1 & 1 & 0.829 \\
& Question 2 & 0.927 & 0.860 \\
Eigenvalue & Question 3 & 0.923 & 0.852 \\
Variance (\%) & & 0.910 & \\
Cumulative (\%) & & 2.540 & \\
Cronbach's $\alpha$ & & 84.677 & \\
Total Cronbach's $\alpha$ & & 0.909 & \\
\hline
\end{tabular}

$\mathrm{KMO}=0.755 ; \mathrm{x}^{2}=586.329 ; p<0.001$. 
(Cronbach's $\alpha$ ) 값은 0.950으로 나타나 통계적 수용 가능한 내적 일 치도를 보였다.

자아존중감 측정도구의 타당성 검증을 위해 요인 분석한 결과 Table 4 와 같다. 측정도구에 사용된 3 문항 모두 요인적재치를 충족 하여 제거 없이 최종 3 문항 모두를 적용되었다. 3 문항은 1 개의 요 인으로 추출되었으며 $\mathrm{KMO}$ 지수는 0.75545 로 표본의 적합성이 확 인되었으며, Bartlett 구성형 검증치는 $\chi^{2}=586.329, p<0.001$ 으 로 변수 간의 상관이 선형적 관계임이 확인되었고 전체변량(Total Variance)은 $84.677 \%$ 의 설명력을 보였다. 하위요인의 신뢰도 (Cronbach's $\alpha$ ) 값은 0.909로 나타나 통계적 수용 가능한 내적일치 도를 보였다.

\section{3. 연령에 따른 블랙컨슈머 행동지각의 평균 차이}

연령에 따른 블랙컨슈머 행동지각(상습성, 억지성, 과도성)의 평 균차이를 분석을 위한 일원분산분석(one-way ANOVA) 결과이다. 블랙컨슈머 행동지각 하위 요인의 평균 차이를 분석한 결과 상습성 $(F=10.473, p<0.001)$ 과 과도성 $(F=3.590, p<0.05)$ 에서 집단 간 통 계적 유의한 차이를 보였다. 이에 사후분석(Scheffe's)을 실시한 결 과 상습성은 20 대, 30 대 집단 보다 40 대, 50 대 이상 집단이 높았으 며, 과도성은 20 대 집단 보다 30 대, 40 대, 50 대 이상 집단이 더 높 은 평균치를 나타냈다. 연령에 따른 블랙컨슈머 행동지각 대한 집단 간 평균 차이를 분석한 결과 Table 5 와 같다. 통계적 유의하게 집단
간 평균의 차이가 있는 것으로 나타났다.

\section{4. 블랙컨슈머, 직무열의, 자아존중감 간의 상관관계}

블랙컨슈머, 직무열의, 자아존중감 간의 상관관계를 분석한 결과 이다. 분석 결과 Table 6 와 같다. 상습성은 직무열의 $(\mathrm{r}=-0.238)$, 자아존중감 $(\mathrm{r}=-0.194)$ 과 통계적으로 유의하게 부적(-) 상관관계를 보였으며, 억지성은 직무열의 $(\mathrm{r}=-0.314)$, 자아존중감 $(\mathrm{r}=-0.329)$ 과 통계적으로 유의하게 부적(-) 상관관계를 보였다. 과도성은 직무열 의 $(\mathrm{r}=-0.155)$, 자아존중감 $(\mathrm{r}=-0.190)$ 과 통계적으로 유의하게 부적 (-) 상관관계를 보였으며, 직무열의는 자아존중감 $(\mathrm{r}=0.514)$ 과 통계 적 유의한 정적(+)상관관계를 보였다.

\section{5. 블랙컨슈머 행동지각이 직무열의에 미치는 영향}

블랙컨슈머 행동지각이 직무열의에 미치는 영향을 규명하기 위 한 다중회귀분석(multi-regression) 결과이다. 본 연구에서는 먼 저 회귀분석 결과를 보다 타당성 있게 검증하기 위하여 다중공선성 (Multicollinearity)을 실시하였다. 다중공선성은 독립변수들 간에 강한 상관이 회귀분석의 전체가정을 위배하는 결과를 초래한다. 일 반적으로 회귀분석에 앞서 다중공선성을 확인하기 위해서는 변수 들 간의 독립성 여부를 검토하는 Durbin-Watson 검증, 공차한계 (tolerance), 분산팽창요인(variance inflation factor, $\mathrm{VIF}$ )등을 확 인한다. 이때 Durbin-Watson 수치는 0-4까지의 값을 가지는데 2

Table 5. Analysis of behavioral perception of black consumers

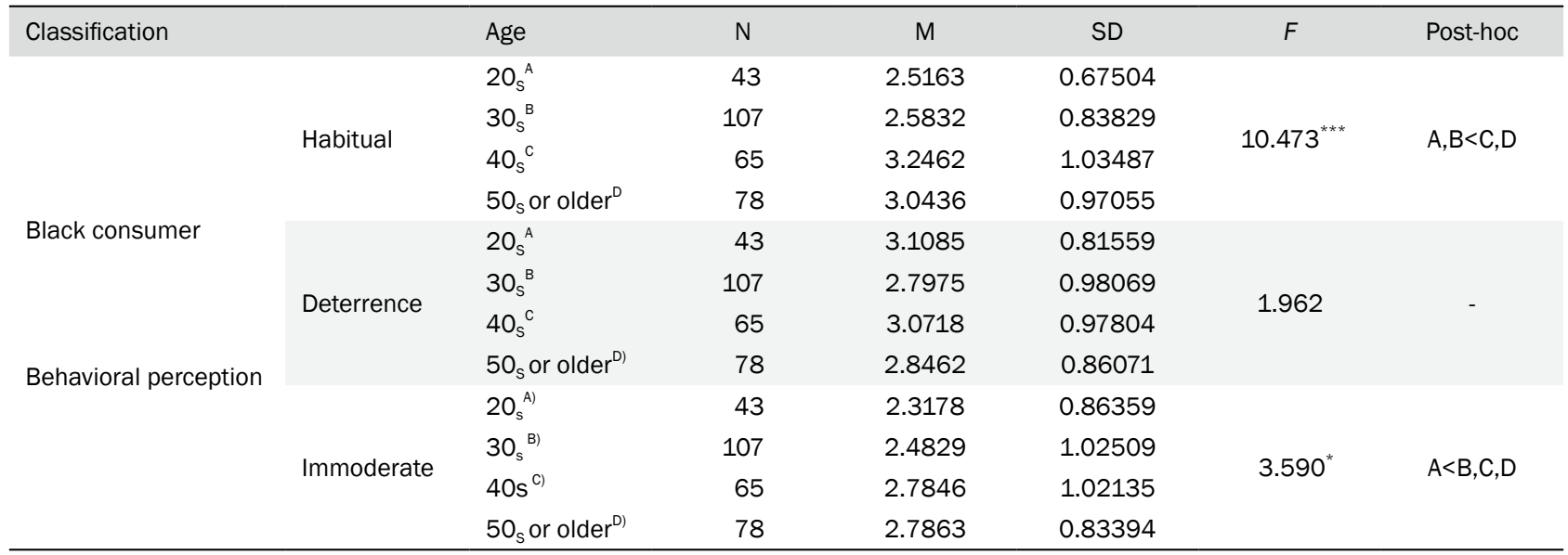

${ }^{*} p<0.05 ;{ }^{* * *} p<0.001$.

Table 6. Correlation of black consumer, job engagement, self-respect

\begin{tabular}{|c|c|c|c|c|c|}
\hline & Habitual & Deterrence & Immoderate & Job engagement & Self-respect \\
\hline Habitual & 1 & & & & \\
\hline Deterrence & $0.625^{* *}$ & 1 & & & \\
\hline Immoderate & $0.585^{* *}$ & $0.584^{* *}$ & 1 & & \\
\hline Job engagement & $-0.238^{* *}$ & $-0.314^{* *}$ & $-0.155^{* *}$ & 1 & \\
\hline Self-respect & $-0.194^{* *}$ & $-0.329^{* *}$ & $-0.190^{* *}$ & $0.514^{* *}$ & 1 \\
\hline
\end{tabular}

${ }^{*} p<0.05 ;{ }^{* *} p<0.01$. 
에 가까우면 변수들 간의 독립성이 확보된 것으로 판단하며, VIF 지 수는 10 미만이면 다중공선성에 문제가 없는 것으로 판단한다. 본 연구의 결과를 토대로 다중공선형의 문제를 확인한 결과 DurbinWatson 값은 1.950 로 2 에 가까워 변수들 간의 자기 상관의 문제 가 없이 독립적으로 나타났으며, 공차 0.536-0.579 이였으며, VIF 값은 1.726-1.864로 나타나 다중공선성의 문제가 없는 것으로 나 타났다. 블랙컨슈머 행동지각이 직무열의에 미치는 영향을 분석 한 결과 독립변수와 종속변수 간의 관계수(R)은 0.323 이였으며 결 정계수 $\left(\mathrm{R}^{2}\right)$ 가 0.104 로 나타나 독립변인이 종속변인에 미치는 설명 력은 $10.4 \%$ 로 나타났다. 또한 회귀모형의 적합도 분산분석 결과, $F=11.239, p<0.001$ 수준에서 통계적 유의하게 나타나 회귀식이 적 합함을 보여주고 있다. 직무열의에 미치는 영향으로 억지성( $\beta=-$ $0.271, t=-3.906, p<0.001)$ 이 통계적으로 유의하게 정적(+) 영향 을 미치고 있는 것으로 Table 7과 같이 나타났다.

블랙컨슈머 행동지각이 자아존중감에 미치는 영향을 규명하기 위한 다중회귀분석(multi-regression) 결과이다. 결과를 살펴보면 Durbin-Watson 값은 1.850 로 2 에 가까워 변수들 간의 자기 상관 의 문제가 없이 독립적으로 나타났으며, 공차 0.536-0.579 이였으 며, VIF 값은 1.726-1.864로 나타나 다중공선성의 문제가 없는 것 으로 나타났다. 블랙컨슈머 행동지각이 직무열의에 미치는 영향을 분석한 결과 독립변수와 종속변수 간의 관계수(R)은 0.330 이였으 며 결정계수 $\left(\mathrm{R}^{2}\right)$ 가 0.109 로 나타나 독립변인이 종속변인에 미치는 설명력은 $10.9 \%$ 로 나타났다. 또한 회귀모형의 적합도 분산분석 결 과 $F=11.734, p<0.001$ 수준에서 통계적 유의하게 나타나 회귀식이 적합함을 보여주고 있다. 직무열의에 미치는 영향으로 억지성 $(\beta=-$ $0.290, t=-4.487, p<0.001)$ 이 통계적으로 유의하게 정적(+) 영향 을 미치고 있는 것으로 Table 8 과 같이 나타났다.

\section{Discussion}

서비스업 종사자는 블랙컨슈머로 인한 언어와 물리적 폭력을 경 험하게 됨으로 과도한 스트레스를 받게 되고 이로 인해 직무열의 및 자존감을 상실하게 되고 직무소진 상태가 되어 이직을 생각하게 된 다(Choi et al., 2017; Pyo \& Park, 2018; Seo \& Park, 2018). 뷰 티 서비스업은 타업종에 비해 이직율이 높아 뷰티 구성원들과 뷰티 산업의 경쟁력강화를 위한 보상제도와 직무에 대한 열의를 가질 수 있는 장치가 필요하다. Kim \& Lee (2018)은 직무만족도가 조직에 대한 충성도와 기업성과 및 고객지향의 매개효과가 되기도 한다고 제시하였다. 따라서 직무열의는 내부 마케팅효과를 극대화할 수 있 고 직무성과 및 기업의 성패를 좌우하는 도구이다.

Shin (2015)의 연구에서는 블랙컨슈머는 고의적인 불만을 표출 하는 사람일수록 자기를 정당화하려는 경향이 높았으며, 상습성이 30 대와 40 대에서 높게 나타났다. 그러나 본 연구에서는 50 대 이상 에서 높게 나타나 Shin (2015)의 연구와는 상반되는 결과를 보였 다.

Seo et al. (2019)의 연구에서는 불량한 고객의 행동지각의 억지 성이 높게 나타나 본 논문의 연구결과와 일치한다. 따라서 연령이 높을수록 제품 및 서비스에 대한 억지주장의 경향성이 높은 것으로 사료된다.

Hong \& Koh (2013)의 연구에서는 미용사의 스트레스 관리가 고 객지향에 미치는 것으로 보고되었다. 그러므로 블랙컨슈머로 인한 뷰티 서비스 종사자의 직무열의와 자아존중감을 향상시킬 수 있는 방안을 강구하여야 한다.

\section{Table 7. Black consumer's perception of behavior}

\begin{tabular}{llccccccc}
\hline $\begin{array}{l}\text { Dependent } \\
\text { variable }\end{array}$ & $\begin{array}{l}\text { Independent } \\
\text { variables }\end{array}$ & $\mathrm{B}$ & $\mathrm{SE}$ & $\beta$ & $t$ & $p$ & Tolerancing & VIF \\
& (Constant) & 4.465 & 0.171 & & 26.133 & 0.000 & & \\
Job & Habitual & -0.087 & 0.068 & -0.097 & -1.272 & 0.204 & 0.536 & 1.864 \\
engagement & Deterrence & -0.271 & 0.069 & -0.297 & -3.906 & 0.000 & 0.537 & 1.862 \\
& Immoderate & 0.066 & 0.064 & 0.075 & 1.020 & 0.309 & 0.579 & 1.726 \\
\hline
\end{tabular}

$\mathrm{R}=0.323^{\text {a }}$ adj $\mathrm{R}^{2}=0.104 ; F=11.239 ; p<0.001 ; \mathrm{D}-\mathrm{W}=1.952$.

Table 8. Effects of black consumer behavioral perception on self-esteem

\begin{tabular}{llllccccc}
\hline $\begin{array}{l}\text { Dependent } \\
\text { variable }\end{array}$ & $\begin{array}{l}\text { Independent } \\
\text { variables }\end{array}$ & $\mathrm{B}$ & $\mathrm{SE}$ & $\beta$ & $t$ & $p$ & Tolerancing & VIF \\
& (Constant) & 4.898 & 0.159 & & 30.767 & 0.000 & & \\
\multirow{2}{*}{ Self-respect } & Habitual & 0.017 & 0.064 & 0.021 & 0.272 & 0.786 & 0.536 & 1.864 \\
& Deterrence & -0.290 & 0.065 & -0.340 & -4.487 & 0.000 & 0.537 & 1.862 \\
& Immoderate & -0.003 & 0.060 & -0.003 & -0.046 & 0.963 & 0.579 & 1.726 \\
\hline
\end{tabular}

$\mathrm{R}=0.330^{\text {a }}$; adj $\mathrm{R}^{2}=0.109 ; F=11.734 ; p<0.001 ; \mathrm{D}-\mathrm{W}=1.850$. 


\section{Conclusion}

본 연구를 통해 블랙컨슈머 행동지각이 뷰티 종사자들의 직무열 의와 자아존중감에 부정 적인 영향을 미치는 것을 확인할 수 있었 다. 그러나 연구참여자 선정에 있어 수도권 지역을 대상으로 하였기 때문에 모든 뷰티 산업 종사자들에게 일반화하기에는 다소 부족함 이 있었다. 이번 연구결과를 바탕으로 블랙컨슈머의 해결방안과 뷰 티 서비스 종사자들의 직무열의 및 자아존중감 향상을 위한 체계적 인 인적자원관리가 계획되고 추진되기를 기대한다.

\section{Author's contribution}

MSC, KBJ and YJL contributed equally to experimental design, data collect and statistical work. MSC wrote manuscript with assistance from KBJ and YJL. YJL oversaw the project and contributed to the revision of the paper.

\section{Author details}

Myo-sun Choi (Student), Department of Health and Cosmetics, Dongduk Women's University, 13-gil, Hwarangro, Seongbuk-gu, Seoul 02748 Korea; Ki-bbeum Jung (Student), Department of Health and Cosmetics, Dongduk Women's University, 13-gil, Hwarang-ro, Seongbuk-gu, Seoul 02748. Korea; Young-jo Lee (Lecture), Department of Hair Beauty Course, Kyung-In Women's University, 63, Gyeyangsan-ro, Gyeyang-gu, Incheon 21041, Korea.

\section{References}

Baumeister RF, Campbell JD, Krueger Jl, Vohs KD. Does high self-esteem cause better performance, interpersonal success, happiness or healthier lifestyles? Psychological Science in the Public Interest, 4: 1-44, 2003.

Choi EM, Kim MY, Hur YK. The effects of customer's bad behavior on job burnout of service encounter employee: focused on the moderating effect of stress coping ability. Tourism Research, 42: 209-235, 2017.

Choi MS, Chang CG. Effects of middle-aged hair loss women's hair increased techniques on quality of life. Journal of Convergence for Information Technology, 10: 175-183, 2020.

Fullerton RA, Punj G. Repercussions of promoting an ideology of consumption: consumer misbehavior. Journal of Business Research, 57: 1239-1249, 2004.
Jang $\mathrm{H}$, Yoon $\mathrm{S}$. The influence of emotional labor of airline cabin crew on black consumer behavior on the intent to stay: focused on mediating effects of job embeddedness. Journal of Tourism Management Research, 90: 93-110, 2019.

Jeon SS. The effects of aesthetician's environment and satisfaction on professional consciousness. Asian Journal of Beauty and Cosmetology, 6: 19-27, 2008.

Jo SY, Hwang SM. A study of effects of gap between actual age and self-perceived age in middle-age women on their appearance management behavior and selfesteem. Asian Journal of Beauty and Cosmetology, 11: 1137-1146, 2013.

Hong SJ, Koh HJ. A study on skin beauticians' stress management on customer orientation. Asian Journal of Beauty and Cosmetology, 11: 399-405, 2013.

Khan. Psychological conditions of personal engagement and disengagement at work. The Academy of Management Journal, 33: 692-724, 1990.

Kim E, Park I, Kim H. A study on the influence of black consumer's customer defect behavior on the disorder and customer orientation of hotel employees. Journal of Tourism Management Research, 71: 43-67, 2016.

Kim TY, Lee SN. The mediating effect of job satisfaction on the relationship between internal marketing and the customer orientation of employees in the beauty service industry. Asian Journal of Beauty and Cosmetology, 16: 555-567, 2018.

Lee EK, Lee EM, Jeon JO. A study on the conceptualization of 'black consumer behavior' and scale development. Journal of Marketing Management Research, 18: 183207, 2013.

Lee HJ, Kim YK. Effects of black consumers' behavior perceived by a travel agent on burnout: mediating effects of self-efficacy. International Journal of Tourism Management and Sciences, 31: 215-230, 2016.

Pyo SJ, Park EJ. A study on difference of jaycustomer behavior and job exhaustion according to beauty service employee. Journal of The Korean Society of Cosmetology, 24: 1070-1076, 2018.

Ryu JH, Kim YS. Influence of interest in appearance of upper elementary school student on makeup behavior and self-esteem. Asian Journal of Beauty and Cosmetology, 18: 17-25, 2020. 
Seo HS, Lee MS, Park SH. The effects of the perception of black consumer behavior on job burnout and mental health in beauty service employees. Journal of the Korean Society of Beauty and Art, 20: 181-196, 2019

Seo SS, Park CH. Effects of emotional labor for aestheticians on job stress, satisfaction, and turnover. Asian Journal of Beauty and Cosmetology, 16: 333-345, 2018.

Shin BS. Black consumer tendency upon demographic characteristics and the effect of black consumer tendency on retaliation intention and self-justification.
The Journal of the Korea Contents Association, 15: 379388, 2015

Shin JW, Shin MC. The effects of consumers' psychological characteristics on dysfunctional consumer behavior and life satisfaction. Korean Journal of Consumer and Advertising Psychology, 15: 409-433, 2014.

Son HI, Park SB. 'Black consumer behavior', and organizational misbehavior: the moderating effects of encourage. Management \& Information Systems Review, 36: 103116, 2017. 


\section{국문초록}

\section{뷰티 서비스 종사자의 블랙컨슈머 행동지각이 직무열의 및 자아존중감에 미치는 영향}

최묘선 ${ }^{1}$, 정기쁨 $^{1}$, 이영조 ${ }^{2 *}$

${ }^{1}$ 동덕여자대학교 보건향장학과, 서울, 한국

${ }^{2}$ 경인여자대학교 헤어뷰티학과, 인천, 한국

목적: 본 연구는 뷰티 산업 종사자의 블랙컨슈머 행동지각이 직무열의와 자아존중감에 미치는 영향에 대하여 연구하는 것을 목적으 로 한다. 방법: 서울, 인천, 경기 지역의 뷰티 서비스업 종사자를 대상으로 2020년 3월 2일부터 한 달간 설문조사를 하였고, 총 293 부를 분석에 사용하였다. 분석방법은 SPSS 25.0 프로그램을 사용하여 빈도분석, 요인분석, 신뢰도분석, 상관관계분석, 일원분산분 석, 사후검증, 다중회귀분석을 수행하였다. 결과: 첫째, 블랙컨슈머 행동지각은 20 대, 30 대 보다 40 대 이상이 많게 나타났다. 둘째, 블랙컨슈머 행동지각이 직무열의와 자아존중감에 부적(-) 상관관계를 보였고, 직무열의와 자아존중감은 서로 정적(+) 상관관계를 보였다. 셋째, 블랙컨슈머 요인 중 억지성이 직무열의에 영향을 미치는 것으로 나타났다. 넷째, 블랙컨슈머 요인 중 억지성이 자아 존중감에 영향을 미치는 것으로 나타났다. 결론: 이번 연구결과는 미용산업 발전을 위한 기초자료로 제공되고, 블랙컨슈머 해결방 안과 뷰티 서비스 종사자들의 직무열의, 자아존중감 향상을 위한 체계적인 인전자원관리가 계획되고 추진되기를 바란다.

핵심어: 뷰티 서비스, 블랙컨슈머, 행동지각, 직무열의, 자아존중감

\section{참고문헌}

김은혜, 박인영, 김혜영. 블랙컨슈머의 고객불량행동이 호텔종사원의 직무소진과 고객지향성에 미치는 영향 연구. 관광경 영연구, 71: 43-67, 2016.

김태열, 이성내. 뷰티서비스업 구성원의 내부 마케팅과 고객지향성의 관계에서 직무만족의 매개효과. 아시안뷰티화장품학 술지, 16: 555-567, 2018.

류진희, 김영삼. 초등학교 고학년의 외모관심도가 화장행동과 자아존중감에 미치는 영향. 아시안뷰티화장품학술지, 18 : $17-25,2020$.

서상숙, 박철호. 피부미용사의 감정노동이 직무스트레스, 직무만족, 이직의도에 미치는 영향. 아시안뷰티화장품학술지, 16: 333-345, 2018.

서현숙, 이미숙, 박현숙. 뷰티서비스종사자의 블랙컨슈머 행동지각이 직무소진 및 정신건강에 미치는 영향. 한국인체미용 예술학회지, 20: 181-196, 2019.

손헌일, 박상봉. '블랙컨슈머 행동'과 종사원의 조직일탈행동: 격려의 조절효과. 경영과 정보연구, 36: 103-116, 2017.

신봉섭. 인구통계적 특성에 따른 블랙컨슈머 성향과 성향이 보복의도와 자기정당성에 미치는 영향. 한국콘텐츠학회논문지, 15: 379-388, 2015.

신재욱, 신민철. 소비자의 심리특성이 블랙컨슈머행동 및 삶의 만족도에 미치는 영향. 한국심리학회지: 소비자·광고, $15:$ 409-433, 2014.

이은경, 이은미, 전중옥. "블랙컨슈머행동"의 개념화와 척도개발에 관한 연구. 마케팅관리연구, 18: 183-207, 2013.

이혜정, 김영규. 여행사 종사원이 지각한 블랙컨슈머의 행동이 소진에 미치는 영향: 자기효능감의 매개효과. 관광연구, 31: 215-230, 2016.

장희숙, 윤선정. 블랙컨슈머의 행동에 대한 항공사 객실승무원의 감정노동이 직무지속의사에 미치는 영향: 직무배태성의 매개효과를 중심으로. 관광경영연구, 90: 93-110, 2019.

전승신. 피부관리사의 직무 환경과 직무만족도가 직업 의식에 미치는 영향. 아시안뷰티화장품학술지, 6: 19-27, 2008. 
조선영, 황승민. 중년여성의 실제연령과 지각연령의 차이가 외모관리행동 및 자아존중감에 미치는 영향. 아시안뷰티화장품 학술지, 11: 1137-1146, 2013.

최묘선, 장창곡. 중년 탈모 여성의 헤어 증모술이 삶의 질에 미치는 영향. 융합정보논문지, 10: 175-183, 2020.

최은미, 김미경, 허윤경. 고객불량행동이 서비스 접점 종사원의 직무소진에 미치는 영향: 스트레스 대처능력의 조절효과 를 중심으로. Tourism Research, 42: 209-235, 2017.

표승지, 박은준. 미용서비스업 종사자의 일반적 특성에 따른 고객 불량행동과 직무소진의 차이. 한국미용학회지, 24: 1070-1076, 2018.

홍승정, 고혜정. 피부미용사의 스트레스가 고객지향성에 미치는 영향에 관한 연구. 아시안뷰티화장품학술지, 11: 399405, 2013. 


\section{中文摘要}

\section{“黑色消费者”行为感知对美容服务人员工作热情和自尊的影响}

崔妙先 ${ }^{1}$, 鄭기쁨 ${ }^{1}$, 李永助 ${ }^{2 *}$

${ }^{1}$ 同德女子大学保健香妆学科，首尔，韩国

2敬仁女子大学美发美容学科，仁川，韩国

目的：探索“黑色消费者”的行为感知对美容行业工作人员的工作热情和自尊心的影响。方法：从2020年3月2日开 始, 对首尔, 仁川和京畿道的美容服务工作者进行了为期1个月的调查, 共进行了293次调查。SPSS 25.0版程序 用于分析频率，因子分析，可靠性分析，相关性分析，方差单向分析，验证后和多元回归分析。结果：发现“黑 色消费者”的行为感知在 40 多岁的人比 20 多岁和 30 多岁的人更多。其次, “黑色消费者” 的行为感知与工作热情和 自尊呈负相关，而工作热情和自尊则呈正相关。结论: 本研究结果为美容行业的发展提供了基础数据, 希望能够 规划和促进系统的人力资源管理，以解决“黑色消费者”的行为观念，并提高美容行业工作者的工作热情。

关键词：美容服务，黑色消费者，行为感知，工作投入，自梅 
